\title{
TITLE: Study of relationships between morphological and agronomic traits of cassava (Manihot esculenta Crantz)
}

\section{ADDITIONAL TITLE : Etude des relations entre les caractères morphologiques et agronomiques du manioc (Manihot esculenta Crantz)}

\section{N'ZUE Boni ${ }^{1}$, KOFFI Adjo Christiane ${ }^{2}$, N'NAN-ALLA Oulo ${ }^{2}$, KOUAKOU Amani Michel ${ }^{1}$, DIBI Konan Evrard Brice ${ }^{1}$, ESSIS Brice Sidoine ${ }^{1}$, NGUETTA Assanvo Simon-Pierre ${ }^{2}$}

\footnotetext{
${ }^{1}$ Centre National de Recherche Agronomique (CNRA), Côte d'Ivoire 01 PO 1740 Abidjan, Phone: (225) 224896 24, Fax. (225) 224896 11, www.cnra.ci,

${ }^{2}$ University Félix Houphouët-Boigny, Côte d'Ivoire, 22 PO 582 Abidjan, Phone: (225) 089708 73,
}

Article No.: 042619079

Type: Research

DOI: 10.15580/GJAS.2019.2.042619079

Submitted: 26/04/2019

Accepted: 01/05/2019

Published: 16/05/2019

${ }^{*}$ Corresponding Author Dr. NZUE Boni

E-mail: nboni1@yahoo.fr Phone: (225) 22489624

Keywords: cassava; Manihot esculenta; morphological traits, agronomic traits;

Mots-clés: manioc; Manihot esculenta; caractères morphologiques; caractères agronomiques
Cassava (Manihot esculenta Crantz) is a food and industrial commodity that plays a very important role in food security and the textile industry for the world's population. It ranks second among food crops after yam, with production estimated at 4.24 million tons in Côte d'Ivoire. In order to preserve the genetic diversity of cassava in the CNRA collection, several studies on morphological and agronomic characterization were carried out. However, no study on the relationship between morphological and agronomic traits has yet been conducted. It is in this context that a trial was carried out on the Adiopodoumé site in Abidjan with 261 accessions used as plant material. Work has shown a relationship between apex color, peduncle length, phelloderm color, adult limb color, average plant production, cooking and taste. In addition, the results revealed a correlation between branching habit, flowering, adult leaf shape, virus disease and dry matter content.

\section{Additional non-english abstract}

Le manioc (Manihot esculenta Crantz) est une denrée alimentaire et industrielle qui joue un rôle très important dans la sécurité alimentaire et l'industrie textile pour la population mondiale. II occupe le deuxième rang des productions vivrières après l'igname avec une production estimée à 4.24 millions de tonnes en Côte d'Ivoire. Dans l'optique de préserver la diversité génétique du manioc de la collection du CNRA, plusieurs travaux portant sur la caractérisation morphologique et agronomique ont été réalisés. Cependant, aucune étude sur la relation entre les caractères morphologiques et agronomiques n'a encore été réalisée. C'est dans ce contexte qu'un essai a été réalisé sur le site d'Adiopodoumé à Abidjan avec 261 accessions utilisées comme matériel végétal. Les travaux ont montré l'existence d'une relation entre la coloration de l'apex, la longueur du pédoncule, la couleur du phelloderme, la couleur du limbe adulte, la production moyenne par plant, la cuisson et le goût. En outre, les résultats ont révélé une corrélation entre le port, la floraison, la forme des feuilles adultes, les viroses et le taux de matière sèche. 


\section{INTRODUCTION}

Cassava (Manihot esculenta Crantz), native to South America, is a starchy plant and important in the tropics. Its ability to store in the soil two to three years after maturation gives it interesting characteristics such as starch accumulation (Kehinde, 2006). Global production in 2016 was estimated at 277 million tons, of which $57 \%$ is from Africa (FAO, 2017). Cassava is used in the textile industry, in the paper industry as an adhesive and in the food industry, as a gelling agent or stabilizer in soups, breads and sauces (Moorthy, 2004). In Côte d'Ivoire, cassava is the second most important food crop after yam, with production estimated at 3.2 million tons in 2015 (FAO, 2017). Cassava provides multiple derived products such as attiéké, placali, foutou, flour, starch and gari (N'Zué, 2007). However, the abandonment of certain traditional varieties by farmers due to factors such as their low yield (less than $15 \mathrm{t} / \mathrm{ha}$ ), their long production cycle and their susceptibility to diseases (virus diseases, anthracnose, root rot) and pests (mites, scale insects, nematodes), contributes significantly to the loss of cassava genetic resources. Faced with these constraints that cause the erosion of genetic resources, a collection of these resources followed by their characterization was carried out. Work on the characterization of cassava varieties using morphological and enzymatic markers was conducted. They made it possible to group the cassava genetic resources into several classes based on the observed qualitative and quantitative characteristics measured (Fleming and Rogers, 1970, Zoundjihékpon, 1986, N'Zué, 2007). Unfortunately, according to the literature consulted, very little work has been done on the relationship between the morphological characters and the agronomic characteristics of the tuberous roots of cassava. However, the morphological characters of aerial organs such as leaves contribute greatly to the accumulation of carbohydrate reserves in the roots from photosynthesis. In addition, variety selection is often based on agronomic traits related to tuberous roots.

The general objective of this work is to improve the conditions for the selection of cassava varieties. Specifically, it involves identifying morphological characters that can be correlated with agronomic traits

\section{MATERIALS AND METHODS}

\section{Trial localization}

The study of the relationship between morphological and agronomic characters was conducted at the CNRA research station in Adiopodoumé $\left(5^{\circ} 19 \mathrm{~N}, 4^{\circ}\right.$ $07 \mathrm{~W}$ and $43 \mathrm{~m}$ ) in southern Côte d'Ivoire. According to Avenard et al. (1971), this region is characterized by a hot and humid sub-equatorial climate (Attiean climate). The rainfall pattern includes two rainy seasons and two dry seasons. A large rainy season from April to July, a short dry season from August to September, a small rainy season from October to November and a long dry season from December to March. This area is dominated by forest vegetation (Caliman 1983). The soils are of ferralitic type strongly desaturated under heavy rainfall (Monnier, 1979), with a sand-clay or sandy texture. Average annual rainfall is about 2000 $\mathrm{mm}$ (Ndabalishye, 1995). Temperatures range from $21.5^{\circ} \mathrm{C}$ (minimum) to $32.2^{\circ} \mathrm{C}$ (maximum) under shelter (Anonymous, 2018).

\section{Plant material}

The plant material used for the study consists of 261 accessions all belonging to the cultivated species Manihot esculenta. These accessions are of various origins, namely, (i) local cultivars, (ii) locally improved varieties, and (iii) foreign introductions in the form of cultivars and improved varieties.

\section{Experimental design}

The experiment was conducted according to the Fisher design in August 2003 on the CNRA's research station in Adiopodoumé. The 261 accessions were planted in strips. Each accession was planted in two rows of 6 plants each, i.e. 12 cuttings per accession with the spacing of $0.80 \mathrm{~m}$ between rows and $0.80 \mathrm{~m}$ between plants. The accessions were separated by $1.30 \mathrm{~m}$. The strips were $1.50 \mathrm{~m}$ apart. Weeding was done on demand.

\section{Observations and measurements}

\section{Morphological traits}

Observations on the aerial part of the plant were made from the 5th month after planting. Those on the underground part were made at harvest, 12 months after planting. A total of 13 morphological characters with 33 modalities were observed on the 261 accessions (Table 1). 
Table 1: Codes and scale scores of qualitative descriptors of cassava (N'Zué, 2007)

\begin{tabular}{|c|c|c|c|c|}
\hline Type of descriptors & Descriptors observed & Code & Modalities & score \\
\hline \multirow{7}{*}{$\begin{array}{l}\text { Leaf and stem descriptors } \\
\text { (observations at } 5 \text { months) }\end{array}$} & Apical leaf colour & CAPE & purple & 1 \\
\hline & Vein leaf colour & CNFE & $\begin{array}{l}\text { green } \\
\text { green }\end{array}$ & $\frac{L}{1}$ \\
\hline & & & other (red, green-red) & 2 \\
\hline & Petiole colour & CPET & $\begin{array}{l}\text { red } \\
\text { green } \\
\text { bi-colour (red>green) } \\
\text { bi-colour (red<green) }\end{array}$ & $\begin{array}{l}1 \\
2 \\
3 \\
4\end{array}$ \\
\hline & Mature leaf colour & CLAD & $\begin{array}{l}\text { dark green } \\
\text { light green }\end{array}$ & $\begin{array}{l}1 \\
2\end{array}$ \\
\hline & Shape of mature leaf (lobes) & FFAD & $\begin{array}{l}\text { narrow } \\
\text { large }\end{array}$ & $\begin{array}{l}1 \\
2\end{array}$ \\
\hline & Apical stem colour & CJTA & $\begin{array}{l}\text { purple } \\
\text { green } \\
\text { green-purple }\end{array}$ & $\begin{array}{l}1 \\
2 \\
3 \\
\end{array}$ \\
\hline \multirow{5}{*}{$\begin{array}{l}\text { Tuberous roots descriptors } \\
\text { (observations at } \\
\text { harvesting ( } 12 \text { months)) }\end{array}$} & Peduncle & LPED & $\begin{array}{l}\text { sessile, short } \\
\text { pedunculate }\end{array}$ & $\begin{array}{l}1 \\
2 \\
\end{array}$ \\
\hline & Shape of tuberous roots & FRTU & $\begin{array}{l}\text { conical dominant } \\
\text { cylindrical dominant }\end{array}$ & $\begin{array}{l}1 \\
2 \\
\end{array}$ \\
\hline & Epidermis colour of tuberous roots & CEPI & $\begin{array}{l}\text { brown } \\
\text { white }\end{array}$ & $\begin{array}{l}1 \\
2 \\
\end{array}$ \\
\hline & Phelloderm colour & CPHE & $\begin{array}{l}\text { pink } \\
\text { white } \\
\text { yellowish }\end{array}$ & $\begin{array}{l}1 \\
2 \\
3 \\
\end{array}$ \\
\hline & Pulp colour & $\mathrm{CCHA}$ & $\begin{array}{l}\text { white } \\
\text { yellow }\end{array}$ & $\begin{array}{l}1 \\
2 \\
\end{array}$ \\
\hline \multirow[t]{3}{*}{ Other descriptors } & Flowering & FLOR & $\begin{array}{l}\text { presence } \\
\text { absence }\end{array}$ & $\begin{array}{l}1 \\
2 \\
\end{array}$ \\
\hline & Branching habit at 12 months & PORT & $\begin{array}{l}\text { spread } \\
\text { semi-spread } \\
\text { erect }\end{array}$ & $\begin{array}{l}1 \\
2 \\
3 \\
\end{array}$ \\
\hline & External stem colour at 12 months & CTIG & $\begin{array}{l}\text { dark } \\
\text { grey } \\
\text { orange } \\
\text { yellowish }\end{array}$ & $\begin{array}{l}1 \\
2 \\
3 \\
4\end{array}$ \\
\hline
\end{tabular}

\section{Agronomic traits}

The measurements included five (5) agronomic traits related to tuberous roots during harvest, 12 months after planting. The incidence of viruses (mosaic) on accessions was made on leaves 5 months after planting (Table 2).

Statistical analyses

The XLSTAT software version 2016.02.27444 was used to study the correlations between morphological and agronomic characters. Principal Component Analysis (PCA) was performed to determine correlations between variables and to obtain principal axes that are linear combinations of the input variables.

\section{RESULTS AND DISCUSSION}

\section{Results}

The principal components analysis (PCA), performed on the quantitative characteristics and qualitative characteristics, allowed to group them in main axes. Only the first 5 main axes (F1, F2, F3 F4 and F5), representing $58.58 \%$ of the total variability, were selected (Table 3). Based on the correlations between variables and factors (Table 4), these 5 axes are characterized as follows (Figures 1 and 2):

- Axis $1(\mathrm{~F} 1)$, representing $20.11 \%$ of the total variability, is characterized by the average production of tuberous roots per plant (Pmoyp), the cooking (cooking), the taste (taste), the coloring of the Apex (CAPE), adult limb staining (CLAD), peduncle length (LPED) and phelloderm staining (CPHE). On this axis, the average production of tuberous roots per plant, the cooking, the taste and the coloration of the phelloderm are positively correlated and are opposed to the color of the apex, the coloring of the adult limbs, the length of the peduncle. These are also positively correlated with each other. These results mean that accessions that have a purple apex, a dark green adult limbus and a short stalk have good average tuberous root production per plant, poor cooking and a bitter taste. Accessions to white or yellowish phelloderm also have a tendency to bad cooking and bad taste. 
- Axis 2 (F2), describing $14.54 \%$ of the variability, is defined by mosaic (Mosa), dry matter content (Tms), adult leaf shape (FFAD), flowering (FLOR) and the port (PORT). Port, mosaic and flowering are positively correlated with each other. But, they are negatively correlated to the dry matter content and the shape of the adult leaves. These results show that spreading individuals with broad leaves, bloom, are less susceptible to mosaic and have a high dry matter content.

- Axis 3 (F3) constituting $11.04 \%$ of the variability is defined by leaf disc staining
(CNFE), petiole staining (CPET) and staining of the young apical stem (CJTA).

- $\quad$ Axis 4 (F4) represents $7.12 \%$ of the variability. It is characterized by the average weight of tuber roots (Pmoyt), stalk coloration (CTIG) and epidermal staining (CEPI). The average weight of the tuberous roots is negatively correlated with stalk and epidermis staining.

- Axis 5 (F5) describing $5.78 \%$ of the total variability is characterized by the form of tuberous roots (FRTU).

Table 2: Agronomic characteristics measured on cassava accessions

\begin{tabular}{lll}
\hline Descriptors & Code & Rating / Unit \\
\hline $\begin{array}{l}\text { Incidence of diseases in the rainy } \\
\text { season, } 5 \text { months later (mosaic) }\end{array}$ & Mosa & $\%$ \\
\hline Average weight of tuberous roots & Pmoyt & $\mathrm{Kg} /$ tuberous roots \\
\hline $\begin{array}{l}\text { Average tuberous root production } \\
\text { per plant }\end{array}$ & Pmoyp & $\mathrm{Kg} /$ plant \\
\hline $\begin{array}{l}\text { Dry matter content } \\
\text { Cooking }\end{array}$ & TMS & $\%$ \\
\hline Taste after cooking & Cuis & good = 1, medium = 2, bad = 3 \\
\hline
\end{tabular}

Table 3: Eigen values of the main axes

\begin{tabular}{lccc}
\hline Factor & Eigen value & Variability $(\%)$ & Cumulative $(\%)$ \\
\hline F1 & 3.821 & 20.108 & 20.108 \\
F2 & 2.762 & 14.535 & 34.644 \\
F3 & 2.098 & 11.043 & 45.686 \\
F4 & 1.352 & 7.118 & 52.804 \\
F5 & 1.098 & 5.778 & 58.582 \\
F6 & 1.031 & 5.425 & 64.007 \\
F7 & 0.930 & 4.897 & 68.903 \\
F8 & 0.797 & 4.196 & 73.099 \\
F9 & 0.786 & 4.137 & 77.236 \\
F10 & 0.725 & 3.817 & 81.053 \\
F11 & 0.575 & 3.026 & 84.079 \\
F12 & 0.513 & 2.702 & 86.780 \\
F13 & 0.455 & 2.396 & 89.177 \\
F14 & 0.447 & 2.352 & 91.529 \\
F15 & 0.428 & 2.250 & 93.779 \\
F16 & 0.350 & 1.844 & 95.623 \\
F17 & 0.324 & 1.704 & 97.327 \\
F18 & 0.264 & 1.389 & 98.716 \\
F19 & 0.244 & 1.284 & 100.000 \\
\hline
\end{tabular}


Table 4: Correlations between variables and factors

\begin{tabular}{llllll}
\hline Factors & \multicolumn{5}{l}{} \\
\cline { 2 - 6 } & F1 & F2 & F3 & F4 & F5 \\
\hline Mosa & -0.500 & $\mathbf{0 . 5 2 9}$ & 0.223 & -0.139 & -0.073 \\
Pmoyt & 0.413 & -0.301 & -0.228 & $-\mathbf{0 . 4 6 0}$ & 0.344 \\
Pmoyp & $\mathbf{0 . 6 0 0}$ & -0.444 & -0.230 & -0.307 & 0.053 \\
Tms & -0.452 & $-\mathbf{0 . 4 7 0}$ & -0.285 & 0.030 & -0.117 \\
Cuis & $\mathbf{0 . 7 5 1}$ & 0.034 & 0.044 & 0.150 & -0.098 \\
Gout & $\mathbf{0 . 6 8 6}$ & 0.290 & -0.044 & 0.018 & 0.021 \\
CAPE & $-\mathbf{0 . 6 7 6}$ & -0.106 & 0.317 & 0.005 & -0.017 \\
CNFE & -0.232 & 0.534 & $-\mathbf{0 . 6 6 0}$ & -0.005 & -0.133 \\
CPET & 0.276 & -0.472 & $\mathbf{0 . 6 7 8}$ & 0.153 & 0.066 \\
CLAD & -0.550 & -0.064 & -0.516 & 0.151 & -0.071 \\
CJTA & 0.245 & 0.089 & $-\mathbf{0 . 3 8 8}$ & 0.290 & -0.286 \\
FFAD & -0.357 & $-\mathbf{0 . 6 8 7}$ & 0.106 & 0.192 & -0.126 \\
FLOR & -0.079 & $\mathbf{0 . 4 1 5}$ & 0.249 & 0.102 & 0.258 \\
PORT & -0.191 & $\mathbf{0 . 7 2 8}$ & 0.243 & -0.024 & 0.214 \\
CTIG & 0.192 & -0.140 & -0.413 & $\mathbf{0 . 4 8 9}$ & 0.174 \\
LPED & $\mathbf{- 0 . 4 9 6}$ & -0.115 & -0.115 & -0.046 & 0.473 \\
FRTU & -0.058 & -0.060 & -0.344 & -0.056 & $\mathbf{0 . 5 9 6}$ \\
CEPI & 0.102 & 0.005 & 0.103 & $\mathbf{0 . 7 5 9}$ & 0.316 \\
CPHE & $\mathbf{0 . 6 2 0}$ & 0.382 & -0.010 & 0.065 & -0.020 \\
\hline
\end{tabular}

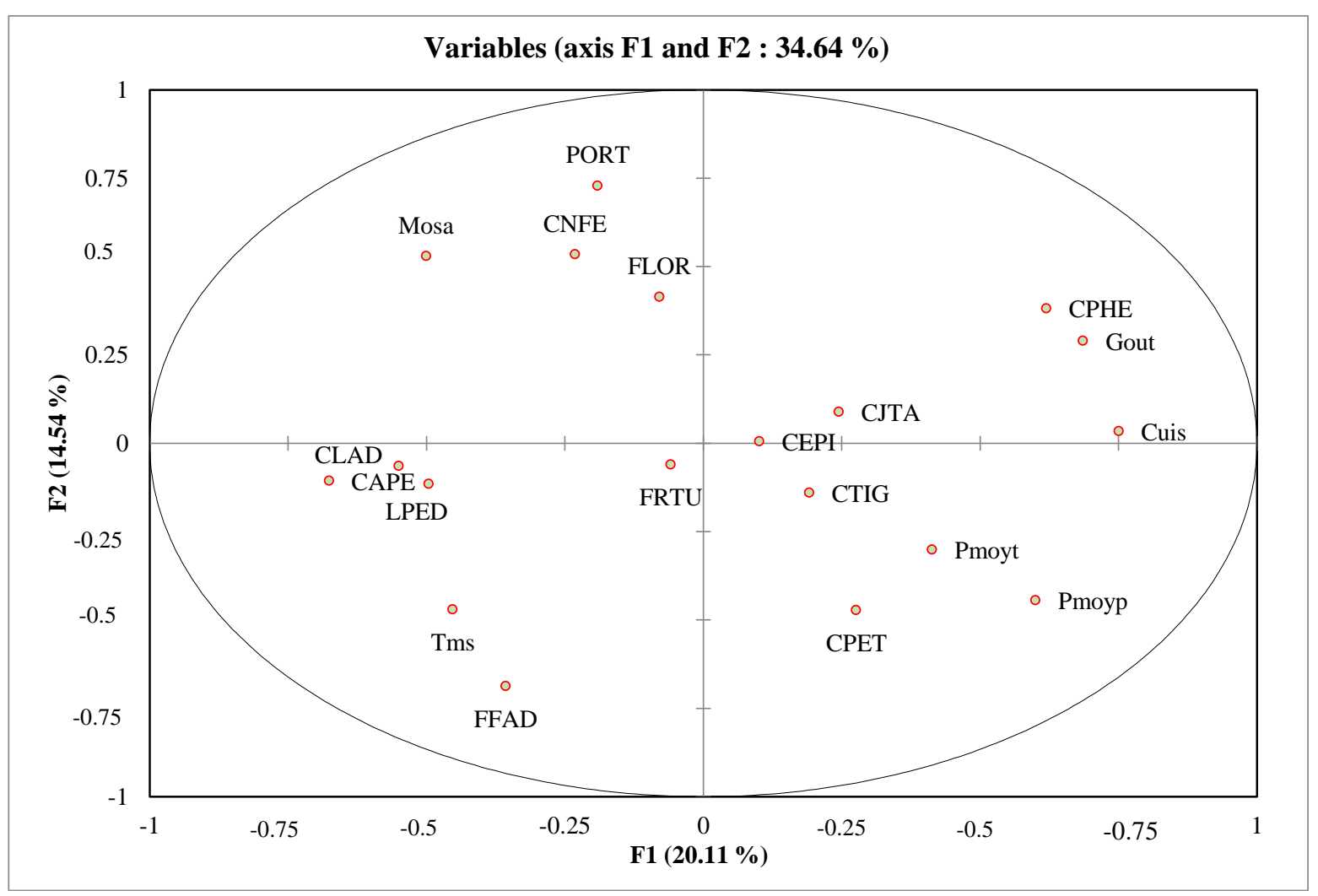

Figure 1: Representation of variables in the main plan (F1. F2) 


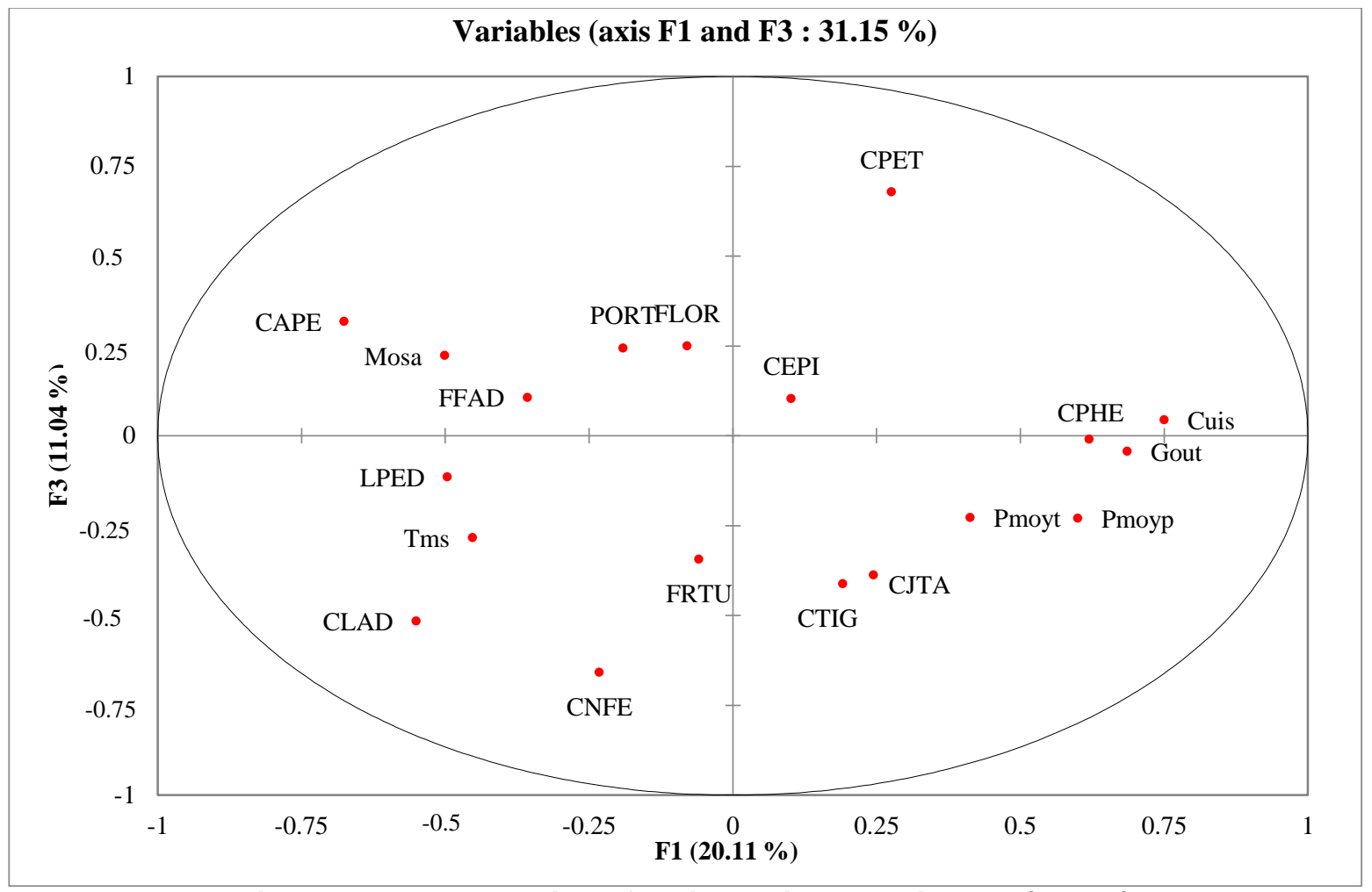

Figure 2: Representation of variables in the main plan (F1. F3)

\section{Discussion}

The analysis of the relationships between morphological and agronomic characters made it possible to identify the most discriminating descriptors that contributed to the formation of the main axes. The first five (5) axes representing $58.58 \%$ of the total variability related the different morphological and agronomic characteristics of cassava. These axes showed that accessions to white or yellowish phelloderm have poor cooking and bad taste. These results are consistent with the results obtained by Okoma (2014) who made the same observation during his work on morphological and agronomic characterization of cassava. The morphological and agronomic characters used for cassava characterization in this study are the same as those used by Okoma (2014). The author asserts that these varieties are predestined for a transformation that involves a fermentation phase such as attiéké, placali, gari. However, these varieties have a good average production per plant and mostly have purple apices, short peduncles and dark green adult limbs. This good production can be explained by the dark green color of the adult limb containing many chlorophylls, thus predisposed to a strong photosynthetic activity. Photosynthesis is the phenomenon that ensures the storage of starch in tuberous roots. This hypothesis is supported by the work of Zinga et al. (2016) who showed that the loss of tuberous root yield is probably due to a chlorophyll deficiency. These authors also indicated that the green color is characteristic of the presence of chlorophyll. The axes have also helped to show that spread accessions are much more resistant to mosaic and have high dry matter content. This can be attributed to the fact that spread accessions are mostly improved varieties. Thus, they had to acquire this resistance when they were created. Hédin's work (1929) confirms this resistance to the mosaic of spread varieties by showing that the Cameroonian peasants fight the mosaic by cultivating the spread varieties. In addition, the majority of these accessions flourish, because flowers are usually born in branching accessions (Eglé, 1992). Broadleaf accessions have higher dry matter content than narrow-leafed accessions. This can also be explained by photosynthesis. Indeed, the larger the leaf, the higher the number of chloroplasts in the cells. Now, photosynthesis takes place in these organelles. It is the basis for the production of carbohydrates that are partly transported to the roots of the tuber to be stored as starch. In 1984, Perez and Villamayor established a strong correlation $\left(R^{2}=0.99\right)$ between starch content and dry matter content in cassava. Therefore, a high starch content would also justify a high material content.

\section{CONCLUSION}

At the end of the study of 261 cassava accessions, it appears that some morphological characters are good indicators that can be used to predict the agronomic characteristics of the tuberous roots. Dark green adult limbus varieties have good production, whereas those with yellow or white phelloderms have a tendency to produce bitter tuberous roots that are unfit for cooking in water. The broadleaf accessions phenotypes have a tendency to produce tuberous roots with high dry matter content. The present study could guide early selection of agronomic traits based on the observation of morphological characters. 


\section{Acknowledgments}

The authors address deep gratitude to Mr KOUADIO Krah, Mr YAO Brou André, Mr DAHA Alphonse and Mr MOYABI Gnanabé, technicians at CNRA and to FISDES project.

\section{REFERENCES}

Anonymous. $2018.2 \quad$ https://fr.climatedata.org/afrique/cote-d-ivoire/abidjan/abidjan-5755/ Accessed October 25. 2018.

Avenard J. M., Eldinn M., Girard O., Sircoulon J., Touchebeuf P., Adjanohoun E. et Perraud A., 1971. Le milieu Naturel de Côte d'Ivoire. ORSTOM. Abidjan. Côte d'Ivoire. 68 p.

Caliman J. P., 1983. Etude comparée de la pluviométrie et du déficit hydrique à la Mé, Abidjan, Dabou. Grand-Drewin. I.R.H.O., Doc n¹789. 71 p. Ibadan, Nigeria: IITA.

Eglé K., 1992. Etude de la variabilité des composantes du rendement du manioc (Manihot esculenta Crantz. var. 312-524) en fonction de la fertilité du sol. Mémoire 91-08 d'Ingénieur Agronome de I'Ecole Supérieure Agronomique de l'Université du Bénin, Lomé, Togo. 111 p.

FAO., 2017. FAOSTAT (statistique de l'organisation des nations unies pour l'alimentation).http://faostat3.fao.org/faostat gateway/go/to/download/Q/QV/F. Consulté le $10 / 02 / 2018$

Fleming H.S. and Rogers D.J., 1970. A Classification of Manihot esculenta Crantz using the information carrying content of a character as a measure of its classificatory rank. Proceedings of the 2nd International Symposium on Tropical Root and Tuber Crops. Hawaii. August. 1970. pp 66-70.

Hédin L., 1929. La culture du manioc au Cameroun, revue de botanique appliquée et d'agriculture coloniale. Vol 9. №3. pp. 311-314.
Kehinde A.T., 2006. Utilization potentials of cassava in Nigeria: the domestic and industrial products. Food Rev. Int., 22 (1). 29-42.

Monnier Y., 1979. Les sols. Les Atlas Jeune Afrique : La Cote d'Ivoire, jeune Afrique, Ed., Paris, jeune Afrique. 20-21.

Moorthy S.N., 2004. «Tropical sources of Starch ». In: Eliasson A.-C.."Starch in food structure, function and application". Woodheard Publishing in Food Science and Technology. PP 321-359.

N'Dabalishye I., 1995. Agriculture vivrière ouest africaine à travers le cas de la Côte d'Ivoire. Institut des savanes. $384 \mathrm{p}$.

N'Zué B., 2007. Caractérisation morphologique, sélection variétale et amélioration du taux de multiplication végétative chez le manioc Manihot esculenta Crantz (Euphorbiaceae). Thèse de Doctorat unique. UFR Biosciences. Université de Cocody-Abidjan. $141 \mathrm{p}$.

Okoma M. P., 2014. Caractérisation morphologique et agronomique des accessions de manioc (Manihot esculenta Crantz) collectées au Centre-ouest. au Sud-ouest et à l'Ouest de la Côte d'Ivoire. Mémoire de Master. Faculté des Sciences Agronomiques (FSA) -Université d'Abomey-Calavi (UAC). Benin. $62 \mathrm{p}$.

Perez. R.D.Villamayor. F.G. Jr., 1984. Relationships among specific gravity. dry matter and starch contents of cassava roots. NSTA [National Science and Technology Authority] Journal (Philippines). ISSN : 0115-2777.

Zinga I., L.R.D., Komba E.K., Beaumon C., Semballa S., 2016. Evaluation de la teneur en protéines et en chlorophylle dans les feuilles de cinq variétés locales du manioc infestées par la mosaïque en République Centrafricaine. Tropicultura. 34 (1) 3-9

Zoundjihépkpon J., 1986. Etude de la variabilité morphophysiologique et enzymatique de cultivars de Manihot esculenta Crantz. Thèse de Doctorat 3e cycle. FAST. Université Nationale de Côte d'Ivoire. $120 \mathrm{p}$. Journal of Agricultural Sciences 9(2): 208-214, http://doi.org/10.15580/GJAS.2019.2.042619079. 